\title{
Evaluasi Pakan Komplit Berbasis Sabut Kelapa Fementasi terhadap Profil Nitrogen Urea Darah dan Kreatinin Sapi Brahman Cross
}

\author{
(EVALUATION OF COMPLETE FEED BASED ON FEMENTED \\ COCONUT HUSK ON BLOOD UREA NITROGEN AND \\ CREATININE PROFILES BRAHMAN CROSS)
}

\author{
Eko Susilo*, Eko Pangestu, Limbang Kustiawan Nuswantara
}

Departemen Peternakan, Fakultas Peternakan dan Pertanian, Universitas Diponegoro

Jl. Prof Soedarto, SH Tembalang, Semarang, Jawa Tengah, Indonesia 50275

*Telepon: +62 8224466 7041; Email: susiloeko851@gmail.com

\begin{abstract}
ABSTRAK
Penelitian bertujuan mengevaluasi efek pemberian pakan komplit berbasis sabut kelapa fermentasi, terhadap konsumsi nutrient, nitrogen cross urea darah dan kreatinin. Materi penelitian menggunakan 12 ekor sapi brahman jantan umur sekitar 8-10 bulan dengan bobot badan 134-187 kg, ditempatkan di dalam kandang individual berukuran $(210 \times 120 \mathrm{~cm})$. Pakan komplit diberikan pada pukul 07.00 dan air minum secara ad libitum. Rancangan penelitian yang digunakan adalah rancangan acak kelompok (RAK) dengan empat perlakuan dan tiga kelompok sapi sebagai ulangan. Perlakuan yang diterapkan berupa pakan komplit berbasis sabut kelapa terfermentasi R1, R2, R3, R4 (15\%, 20\%, 25\%, 30\%). Perhitungan konsumsi dan pengambilan sampel darah dilakukan pada akhir masa pemeliharaan. Data yang diperoleh dianalisis dengan sidik ragam taraf $5 \%$, adanya pengaruh nyata antar perlakuan dilanjutkan dengan uji jarak berganda duncan. Perlakuan pakan komplit berbeda nyata $(\mathrm{P}<0.05)$ terhadap konsumsi serat kasar/SK dan bahan ekstrak tanpa nitrogen/BETN dan rasio nitrogen urea darah dan kreatinin, tetapi tidak berbeda nyata $(\mathrm{P}>0,05)$ terhadap konsumsi bahan kering/BK, bahan orgaik/BO, protein kasar/PK, kreatinin, nitrogen urea darah dan nitrogen urea darah/kreatinin. Simpulan penelitian adalah perlakuan R1 pakan komplit munujukan konsumsi SK tertinggi sedangkan konsumsi BETN terendah dan hasil rasio nitrogen urea darah/kreatinin terendah tetapi masih dalam kisaran normal. Perlakuan pakan komplit dari hasil data parameter nitrogen urea darah dan kreatinin sebagai indikator penting fungsi ginjal, pakan komplit aman dan tidak menyebabkan ganggan fungsi ginjal.
\end{abstract}

Kata-kata kunci: sabut kelapa fermentasi; konsumsi; nitrogen urea darah; kreatinin

\begin{abstract}
This study aimed to evaluate the effect of complete fermented coconut husk-based feeding on the consumption of nutrients, blood urea nitrogen and creatinine. The material used 12 male brahman cross cows, aged 8-10 months with body weight of $134-187 \mathrm{~kg}$, placed in individual cages with size (210 x 120 $\mathrm{cm})$. Complete feed was given at 07.00 and drinking water ad libitum. The research design used was a randomized block design (RBD) with 4 treatments and 3 groups of cows as replications. The treatment applied was complete feed based on fermented coconut husk R1, R2, R3, R4 (15\%, 20\%, 25\%, 30\%). Consumption calculations and blood sampling were performed at the end of the maintenance period. The data obtained were analyzed by means of a $5 \%$ level of variance. The complete feed treatment was significantly different $(\mathrm{P}<0.05)$ on the consumption of $\mathrm{CF}$, NNFE and the ratio of blood urea nitrogen and creatinine, but not significantly different $(\mathrm{P}>0.05)$ on consumption of $\mathrm{DM}, \mathrm{OM}, \mathrm{CP}$, creatinine, blood urea nitrogen and the ratio of blood urea nitrogen/creatinine. The conclusion of this research is that complete R1 feed treatment shows the highest CF consumption while the lowest NNFE consumption and the lowest blood urea nitrogen/creatinine ratio but still in the normal range. Blood urea nitrogen and creatinine from the complete feed treatment did not interfere with kidney function.
\end{abstract}

Keywords: fermented coconut husk; consumption; blood urea nitrogen; creatinine 


\section{PENDAHULUAN}

Sapi brahman cross merupakan salah satu ternak penghasil daging di Indonesia dengan pertambahan bobot badan yang cukup baik. Menurut Kuswati et al. (2014) pada sapi brahman cross putih mempunyai pertambahan bobot badan harian 0,86-1,03 kg/ekor/hari. Salah satu faktor untuk mendukung swadaya daging sapi yaitu aspek manajemen pakan. Manajemen pemeliharaan sapi di perusahaan pada umumnya sudah dilakukan secara modern, baik dari sisi manajemen pemberian pakan, manajemen perkandangan hingga manajemen kesehatan sapi (Hamdani et al., 2018). Bahan pakan dari segi kualitas, kuantitas dan kontinuitas merupakan faktor penting untuk mendukung produksi ternak ruminansia. Peternak sapi potong semakin memperhatikan berbagai faktor yang memengaruhi efisiensi pakan ternak (Cantalapiedra-Hijar et al., 2018; Uyeh et al., 2019). Pengiriman pakan komplit ditandai dengan konsistensi tinggi dalam komposisi fisik dan kimia sangat penting dalam memaksimalkan hasil dan efisiensi produktivtas (Sova et al., 2013; Sova et al., 2014).

Sabut kelapa merupakan hasil samping industri perkebunan yang mempunyai potensi sebagai komponen pakan alternatif. Produksi perkebunan kelapa menghasilkan 2.900.000 ton (BPS, 2018) dan menghasilkan sabut sebanyak $35 \%$. Sabut kelapa mengandung kadar air $5,43 \%$, abu $3,95 \%$, hemiselulosa $23,70 \%$, lignin (3,54\%) dan selulosa 32,69\% (Adeyi, 2010), kadar hemiselulosa $10,67 \%$, serat kasar $62,11 \%$, lignin (30, 18\%) dan selulosa 25,63\% (Wibowo et al., 2019). Sabut kelapa tidak dapat langsung diberikan pada ternak karena kualitas nutrien yang rendah dan sulit dicerna perlu adanya teknologi fermentasi. Penurunan kadar selulosa ini dapat terjadi dengan peningkatan jumlah pemberian starter saat fermentasi, membuat kemampuan mendegradasi selulosa menjadi lebih tinggi (Nuswantara et al., 2020). Fermentasi merupakan salah satu teknologi meningkatkan nilai nutrien pakan berserat tinggi sebelum dijadikan bahan pakan komplit (Munawaroh et al., 2015). Pakan komplit berbahan hasil sampingan suatu produk, merupakan salah satu alternatif pemecahan masalah ketersediaan bahan pakan untuk ruminansia (Purbowati et al., 2007).

Sistem pemberian pakan dan cara pemeliharaan sangat memengaruhi nilai kimia darah ternak (Klinkon dan Jeek, 2012; Xuan et al., 2018). Pemeriksaan darah dan penentuan nilai biokimia serum dapat memberikan informasi berharga mengenai status nutrisi dan faktor lingkungan yang memengaruhi kesehatan ternak (Al-Fartosi et al., 2010). Status setiap individu ternak tergantung pada asupan pakan dan efektivitas proses metabolismenya. Konsumsi pakan ternak ruminansia dibatasi oleh jumlah nutrien yang tersedia untuk metabolisme ternak. Menurut Chuzaemi (2012) pada tingkat metabolik, konsumsi pakan merupakan respons kurangnya energi dalam tubuh ternak, untuk memenuhi kebutuhan energinya ternak akan mulai makan dan berhenti bila kebutuhan energinya terpenuhi. Menurut Pond et al. (2005) protein termasuk bahan organik yang sangat penting bagi organisme. Menurut Astuti et al. (2008) kadar protein darah dipengaruhi oleh beberapa hal seperti konsumsi, kualitas ransum dan waktu pengambilan darah, status fisiologis, umur dan kesehatan.

Sebelum diberikan secara luas pakan komplit harus diuji keamanannya karena pakan komplit disusun dengan kandungan protein kasar tinggi. Katabolisme protein menghasilkan urea kemudian diekskresikan melalui ginjal. Peningkatan kandungan urea nitrogen dalam darah dapat memperberat kerja ginjal dan merupakan salah satu indikasi gangguan fungsi ginjal. Salah satu pemeriksaan fungsi ginjal adalah melalui pemeriksaan urea nitrogen darah dan kreatinin. Menurut Astuti et al. (2008) status metabolit darah dapat dijadikan sebagai indikator kesehatan ternak. Gangguan fungsi ginjal dapat ditunjukkan dengan adanya peningkatan kadar blood urea nitrogen (BUN) dan kreatinin dalam darah. Menurut Gurung et al. (1998), pengaruh pemberian pakan ternak terhadap fungsi ginjal dapat diperiksa berdasarkan pemeriksaan kadar kreatinin dan nitrogen urea darah dalam serum darah. Konsumsi nutrien berpengarh terhadap performa dan mengevaluasi dampak konsumsi nutrien serta profil kreatinin dan nitrogen urea darah pada sapi menjadi penting dari setiap nutrien yang berikan. Penelitian ini bertujuan mengevaluasi efek pemberian pakan komplit berbasis sabut kelapa fermentasi terhadap konsumsi nutrien dan profil darah (kreatinin dan nitrogen urea darah) pada sapi brahman cross. 


\section{METODE PENELITIAN}

Penelitian ini menggunakan 12 ekor sapi brahman cross (jantan) umur sekitar 8-10 bulan dengan bobot badan 134-187 kg, ditempatkan di dalam kandang individual berukuran (210 x 120 $\mathrm{cm}$ ), penelitian berlangsung 14 hari adaptasi pakan, 90 hari untuk perlakuan dan koleksi data. Pakan berupa pakan komplit dan air minum diberikan pada pukul 07.00 secara $a d$ libitum. Rancangan penelitian yang digunakan adalah rancangan acak kelompok (RAK) dengan empat perlakuan dan tiga kelompok bobot badan sebagai ulangan. Perlakuan yang diterapkan berupa pakan komplit R1; berbasis sabut kelapa terfermentasi $15 \%$, R2; berbasis sabut kelapa terfermentasi $20 \%$, R3; berbasis sabut kelapa terfermentasi $25 \%, \mathrm{R} 4$; berbasis sabut kelapa terfermentasi $30 \%$.

\section{Parameter Penelitian}

Parameter yang diamati dalam penelitian ini adalah konsumsi nutrien pakan yang meliputi bahan kering/BK, bahan organik/BO, protein kasar/PK, serat kasar/SK bahan ekstrak tanpa nitrogen/BETN dan profil darah (keratinin dan nitrogen urea darah).

Pengambilan data dilakukan dengan metode sebagai berikut:

Konsumsi. Konsumsi pakan dihitung dengan cara menimbang pakan sebelum diberikan pada ternak dikurangi dengan sisa pakan yang tidak terkonsumsi. Konsumsi nutrien pakan yang meliputi BK, BO dan PK. Berikut ini disajikan rumus konsumsi (Purbowati et al., 2004).

a. Konsumsi BK (kg/ekor/hari) = Pakan yang diberikan $(\mathrm{kg}) \mathrm{x} \%$ BK pakan (\%) - sisa pakan (kg) x \% BK; b. Konsumsi BO (kg/ekor/ hari) $=$ konsumsi BK pakan $(\mathrm{kg}) \mathrm{x} \% \mathrm{BO} ; \quad \mathrm{c}$. Konsumsi PK (kg/ekor/hari) = konsumsi BK pakan (kg) x \% PK; d. Konsumsi SK (kg/ekor/ hari) $=$ konsumsi BK pakan $(\mathrm{kg}) \mathrm{x} \% \mathrm{SK}$; e. Konsumsi BETN (kg/ekor/hari) = konsumsi BK pakan (kg) x \% BETN

Profil Darah. Pengambilan sampel darah

Tabel 1. Perlakuan dan kandungan nutrien pakan komplit berbasis sabut kelapa fermentasi

\begin{tabular}{|c|c|c|c|c|}
\hline \multirow{2}{*}{ Bahan Pakan } & \multicolumn{3}{|c|}{ Perlakuan } & \multirow[b]{2}{*}{$\mathrm{R} 4$} \\
\hline & $\mathrm{R} 1$ & $\mathrm{R} 2$ & $\mathrm{R} 3$ & \\
\hline \multicolumn{5}{|l|}{ Komposisi } \\
\hline Bungkil Sawit & 15,00 & 15,00 & 14,00 & 7,00 \\
\hline Jagung Kuning & 20,00 & 20,00 & 22,00 & 25,00 \\
\hline Sabut Kelapa terfermentasi & 15,00 & 20,00 & 25,00 & 30,00 \\
\hline Dedak & 14,00 & 7,00 & 5,00 & 4,00 \\
\hline Bungkil biji kapok & 8,00 & 8,00 & 6,00 & 7,00 \\
\hline Kulit kopi & 6,00 & 6,00 & 3,00 & 2,00 \\
\hline Minyak & 1,00 & 1,00 & 1,00 & 1,00 \\
\hline Bungkil kelapa & 10,00 & 12,00 & 13,00 & 17,00 \\
\hline $\mathrm{CaCO} 3$ & 0,20 & 0,20 & 0,10 & 0,20 \\
\hline Garam & 0,20 & 0,20 & 0,10 & 0,10 \\
\hline Tetes & 10 & 10 & 10 & 6 \\
\hline Urea & 0,6 & 0,6 & 0,8 & 0,7 \\
\hline Komposisi Nutrien & & 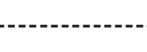 & ........- & -..--.-- \\
\hline BK & 88,53 & 88,39 & 87,15 & 87,20 \\
\hline BO & 91,37 & 90,85 & 90,10 & 92,72 \\
\hline PK & 11,14 & 11,62 & 12,29 & 12,41 \\
\hline LK & 4,52 & 4,00 & 4,51 & 5,15 \\
\hline SK & 32,53 & 28,85 & 31,21 & 30,41 \\
\hline BETN & 43,19 & 46,39 & 42,09 & 44,75 \\
\hline GE (kal/g) & 3633.51 & 3634.92 & 3739.36 & 3683.83 \\
\hline
\end{tabular}

Keterangan: BETN, bahan ekstrak tanpa nitrogen; GE, gross energy; R1= berbasis sabut kelapa terfermentasi 15\%; R2= berbasis sabut kelapa terfermentasi $20 \%$; R3= berbasis sabut kelapa terfermentasi 25\%; R4= berbasis sabut kelapa terfermentasi $30 \%$. 
dilakukan pada akhir perlakuan selama pemeliharaan, pada saat sebelum sapi diberi pakan. Sampel darah sebanyak $3 \mathrm{~mL}$ diambil dari masing-masing sapi melalui vena jugularis dengan spuit (ukuran $10 \mathrm{~mL}$ ), kemudian pengukuran kreatini dan nitrogen urea darah dilakukan dengan cara sampel darah yang telah diperoleh disentrifuge selama 15 menit dengan kecepatan 3000 rpm untuk diambil plasma. Plasma yang telah diperoleh dianalisis kadar kreatinin dan nitrogen urea darah dengan menggunakan alat spektofotometer microlab 300. Data dianalisis ragam pada taraf 5\% jika terdapat perbedaan nyata dilanjutkan dengan uji jarak berganda duncan (Harjosuwono et al., 2011).

\section{HASIL DAN PEMBAHASAN}

Hasil analisis ragam menunjukkan bahwa perlakuan pakan komplit berpengaruh nyata $(\mathrm{P}<0,05)$ terhadap konsumsi SK, BETN dan rasio nitrogen urea darah, dan tidak berpengaruh nyata $(\mathrm{P}>0,05)$ terhadap konsumsi $\mathrm{BK}$, BO dan PK. Hasil analisis ragam dilanjutkan uji Duncan ditampilkan pada Tabel 2 dan profil darah (kreatinin dan nitrogen urea darah) ditampilkan pada Tabel 3.

\section{Konsumsi Bahan Kering (BK)}

Hasil uji jarak berganda duncan terhadap konsumsi BK (g/kg BB $\left.{ }^{0,75}\right)$ menunjukkan bahwa tidak ada perbedaan nyata $(\mathrm{P}>0,05)$ antar perlakuan R1, R2, R3 dan R4. Hal tersebut terjadi karena dipengaruhi oleh kualitas nutrien yang relatif sama. Kearl (1982) menyatakan bahwa konsumsi pakan antara lain dipengaruhi oleh bobot hidup ternak. Arora (1989) menyatakan bahwa konsumsi BK pakan dipengaruhi oleh bobot badan, temperatur lingkungan dan karakteristik pakan yang meliputi kecernaan, palatabilitas, dan keseimbangan nutrisi dalam ransum. Konsumsi BK pada sapi, banyak dipengaruhi oleh laju pencernaan bahan pakan dalam saluran pencernaan, laju pengeluaran sisa pakan yang dikonsumsi, dan tingkat pemenuhan nutrisi oleh bahan pakan yang dikonsumsi (Tillman et al., 1998). Menurut Utomo (2001) banyak sedikitnya konsumsi nutrisi tergantung pada jumlah BK pakan yang dikonsumsi ternak dan kandungan nutrisi dalam pakan yang diberikan. Menurut Van Soest (1994), konsumsi pakan merupakan banyaknya pakan yang dapat dimakan pada periode waktu tertentu yang merupakan faktor untuk menentukan fungsi dan respons ternak terhadap penggunaan pakan.

\section{Konsumsi Bahan Organik (BO)}

Hasil uji jarak bergada duncan terhadap konsumsi BO $\left(\mathrm{g} / \mathrm{kg} \mathrm{BB}^{0,75}\right)$ dari perlakuan pakan komplit tidak berbeda nyata $(\mathrm{P}>0,05)$ antar perlakuan R1, R2, R3 dan R4. Hal tersebut terjadi karena kandungan $\mathrm{BO}$ relatif sama sehingga tidak berpengaruh nyata terhadap konsumsi BO pakan per kg BBM. Konsumsi pakan $\mathrm{BO}$ sangat dipengaruhi oleh kandungan protein dan SK bahan penyusun pakan yang digunakan (Endrawati et al., 2010).

\section{Konsumsi Protein Kasar (PK)}

Hasil uji jarak bergada duncan terhadap konsumsi PK (g/kg BB $\left.{ }^{0,75}\right)$ dari perlakuan pakan komplit tidak berbeda nyata $(\mathrm{P}>0,05)$ antar perlakuan R1, R2, R3 dan R4. Konsumsi PK berkitan erat dengan jumlah konsumsi BK dan BO dan kandungan nutrien PK. Purbowati et al. (2007) menyatakan bahwa faktor yang memengaruhi konsumsi PK adalah konsumsi BK dan kandungan PK pakan. Menurut Pond et al. (2005), protein termasuk bahan organik yang sangat penting bagi organisme.

\section{Konsumsi Serat Kasar (SK)}

Hasil uji jarak berganda duncan terhadap konsumsi SK (g/kg BB $\left.{ }^{0,75}\right)$ dari perlakuan jenis pakan komplit menunjukkan perlakuan R1 mengkonsumsi SK nyata lebih tinggi $(\mathrm{P}<0,05)$ dibandingkan R2, R3 dan R4. Pakan komplit menunjukkan R2 megkonsumsi SK nyata lebih tinggi $(\mathrm{P}<0,05)$ dibandingkan R3 dan R4. Pakan komplit menunjukkan R3 mengkosumsi SK nyata lebih tinggi $(\mathrm{P}<0,05)$ dibandingkan $\mathrm{R} 4$. Konsumsi SK berkitan erat dengan jumlah konsumsi BK dan BO dan kandungan nutrien SK. Konsumsi BK dan BO pada R1 lebih tinggi dari konumsi SK R2, R3, R4. Perbedaan yang nyata konsumsi SK per kg BBM terjadi karena kandungan nutrien SK R1 lebih tinggi dibanding perlakuan lainnya, hal ini mengakibatkan konsumsi SK per kg BBM pada R1 tinggi. Kandungan serat yang berbeda diduga menjadi salah satu faktor penyebab nilai konsumsi SK tinggi. Menurut Toharmat et al. (2006) jenis pakan kaya serat dapat memengaruhi konsumsi bahan kering yang selanjutnya memengaruhi konsumsi nutrien SK. 
Tabel 2. Hasil Uji Duncan terhadap Konsumsi Nutrien pada sapi brahman cross pada berbagai perlakuan sabut kelapa terfermentasi

\begin{tabular}{|c|c|c|c|c|}
\hline \multirow{2}{*}{ Parameter } & \multicolumn{4}{|c|}{ Perlakuan } \\
\hline & $\mathrm{R} 1$ & $\mathrm{R} 2$ & R3 & R4 \\
\hline Konsumsi & \multicolumn{4}{|c|}{ g/kg BBM ${ }^{075}$ hari) } \\
\hline BK & 99,00 & 95,95 & 93,95 & 86,32 \\
\hline BO & 90,46 & 87,17 & 84,65 & 80,03 \\
\hline PK & 11,35 & 11,14 & 12,07 & 11,05 \\
\hline SK & $43,39^{\mathrm{a}}$ & $39,62^{\mathrm{b}}$ & $34,71^{\mathrm{c}}$ & $22,29^{\mathrm{d}}$ \\
\hline BETN & $20,22^{\mathrm{b}}$ & $21,43^{\mathrm{b}}$ & $22,09^{b}$ & $31,54^{\mathrm{a}}$ \\
\hline
\end{tabular}

Keterangan: Superskrip berbeda pada baris yang sama menunjukkan perbedaan nyata $(\mathrm{P}<0,05)$; $\mathrm{R} 1=$ berbasis sabut kelapa terfermentasi $15 \%$; R2= berbasis sabut kelapa terfermentasi $20 \%$; $\mathrm{R} 3=$ berbasis sabut kelapa terfermentasi $25 \%$; R4= berbasis sabut kelapa terfermentasi $30 \%$.

Tabel 3. Hasil uji jarak berganda duncan terhadap profil kreatinin, nitrogen urea darah dan nitrogen urea darah/kreatinin sapi brahman cross pada berbagai perlakuan sabut kelapa terfermentasi

\begin{tabular}{lcccc}
\hline \multirow{2}{*}{ Parameter } & \multicolumn{4}{c}{ Perlakuan } \\
\cline { 2 - 5 } & $\mathrm{R} 1$ & $\mathrm{R} 2$ & $\mathrm{R} 3$ & $\mathrm{R} 4$ \\
\hline Kreatinin (mg/dL) & 1,41 & 1,18 & 1,32 & 1,48 \\
Nitrogen urea darah (mg/dL) & 16,37 & 18,00 & 20,83 & 20,86 \\
Nitrogen urea darah/ Kreatinin & $11,68^{\mathrm{b}}$ & $15,46^{\mathrm{a}}$ & $15,71^{\mathrm{a}}$ & $13,95^{\mathrm{ab}}$ \\
\hline
\end{tabular}

Keterangan: Superskrip a,b pada baris yang sama menunjukkan perbedaan nyata $(\mathrm{P}<0,05)$; $\mathrm{R} 1=$ berbasis sabut kelapa terfermentasi 15\%; R2= berbasis sabut kelapa terfermentasi $20 \%$; R3= berbasis sabut kelapa terfermentasi $25 \%$; R4= berbasis sabut kelapa terfermentasi $30 \%$.

\section{Konsumsi Bahan Ekstrak Tanpa Nitrogen (BETN)}

Hasil uji jarak berganda duncan terhadap konsumsi BETN (g/kg BB $\left.{ }^{0,75}\right)$ perlakuan jenis pakan komplit menunjukkan R4 mengkonsumsi BETN nyata lebih tinggi $(\mathrm{P}<0,05)$ dibandingkan R1, R2 dan R3. Perlakuan pakan komplit R1 menunjukkan bahwa kosumsi BETN tidak berbeda nyata $(\mathrm{P}>0,05)$ dengan $\mathrm{R} 2$ dan R3. Konsumsi BETN berkitan erat dengan jumlah konsumsi BK, BO (SK, PK, LK) dan kandungan nutrien BETN. Menurut Purbowati et al. (2007) bahwa faktor yang memengaruhi konsumsi BETN adalah konsumsi BK dan kandungan BETN pakan. Konsumsi BETN erat kaitannya dengan kecukupan energi. Pemenuhan kebutuhan energi diarahkan pada pemenuhan energi untuk hidup pokok, produksi dan reproduksi. Hadi et al. (2011) menyatakan bahwa pakan yang mengandung fraksi mudah larut dalam rumen akan mudah terdegradasi mikroba rumen yang akan meningkatkan konsumsi.

\section{Nitrogen Urea Darah dan Kreatinin}

Hasil uji jarak bergada duncan terhadap nitrogen urea darah, kreatinin dan rasio nitrogen urea darah dan kreatinin dari perlakuan pakan komplit tidak berbeda nyata $(\mathrm{P}>0,05)$ antar perlakuan R1, R2, R3 dan R4. Nitrogen urea darah menggambarkan keseimbangan antara pembentukan urea dan katabolisme protein serta ekskresi urea oleh organ ginjal. Hasil penelitian nitrogen urea darah berada pada kisaran normal 16,37-20,86 mg/dL. Berdasarkan nilai yang diperoleh menunjukan terjadi peningkatan setiap perlakuan, hal ini diduga karena adanya korelasi dengan kandungan PK yang relatif meningkat dari 
perlakuan pakan komplit (Tabel 1), dan konsumsi BETN (Tabel 2) untuk produksi ATP sebagai energi proses sitesis mikrob. Menurut pendapat Widhyari et al. (2015) kadar urea darah yang terdapat pada sapi laktasi berkisar 10-19 $\mathrm{mg} / \mathrm{dL}$, sedangkan kadar nitrogen urea darah pada sapi berkisar antara 6-27 mg/dL (Meyer dan Harvey, 2004).

Kadar nitrogen urea darah yang tidak berbeda nyata kemungkinan disebabkan oleh faktor nutrien protein pakan, konsumsi protein dan waktu pengambilan darah yang relatif sama. Menurut Astuti et al. (2008) kadar protein darah dipengaruhi konsumsi PK, kualitas ransum dan waktu pengambilan darah, status fisiologis hewan, umur dan kesehatan. Kadar urea dalam darah dapat dipengaruhi oleh kadar amonia dalam rumen (McDonald et al., 2002). Promkot dan Wanapat (2005) menyatakan bahwa terdapat hubungan yang positif antara urea darah dan protein pakan yang dikonsumsi oleh ternak. Tingginya protein pakan dapat menyebabkan meningkatnya kandungan urea dalam darah (Duncan dan Prasse, 1986). Menurut Murray et al. (2006) ruminansia yang mendapatkan tambahan protein pada pakannya memiliki konsentrasi urea darah yang tinggi. Menurut Church (1993) protein mikrob dalam rumen meningkat kurang lebih $44 \%$ setelah enam jam pemberian pakan. Ion amonia dengan ATP dan intermediet amfibolik bereaksi dengan bantuan enzim mikrob membentuk asam amino untuk sintesis protein mikroba. ATP diperoleh dari BETN dan sumber karbohidrat yang lain. Ion amonia diperoleh melalui pemecahan non protei nitrogen $(\mathrm{NPN})$ sedangkan intermediet amfibolik berasal dari siklus asam sitrat. Kebutuhan ATP yang tinggi dalam rumen menunjukkan semakin tinggi protein mikrob yang dihasilkan (Murray et al., 2003).

Pengukuran konsentrasi urea darah berguna untuk menentukan tingginya $\mathrm{N}-\mathrm{NH}_{3}$ di dalam rumen dan rendahnya konsumsi energi oleh ternak. Semakin tinggi kadar urea darah, maka semakin besar pula energi yang dibutuhkan untuk mengkonversikan konsentrasi amonia rumen yang tinggi menjadi amonia darah yang selanjutnya disekresikan dalam bentuk urea dalam urin (Purbowati et al., 2007). Hasil metabolit ini sebagian diekskresikan melalui ginjal. Konsentrasi urea dalam serum atau plasma, yang ditentukan dengan kandungan nitrogen, merupakan salah satu indikator penting fungsi ginjal (Sennang et al., 2005). Peningkatan kadar nitrogen urea darah dapat disebabkan oleh peningkatan jumlah metabolism protein, sedangkan peningkatan kadar kreatinin di dalam darah dapat disebabkan oleh adanya kerusakan ginjal, terutama karena gangguan filtrasi glomerulus. Namun demikian, adanya peningkatan kadar nitrogen urea darah dan kreatinin dalam darah tidak selalu mengindikasikan adanya gangguan fungsi ginjal.

Kreatinin merupakan produk akhir metabolism kreatin-fosfat yang terjadi di dalam otot. Kreatinin yang terbentuk akan dilepaskan ke dalam sirkulasi darah, kemudian dialirkan melalui sirkulasi darah menuju ke organ ginjal. Kreatinin difiltrasi oleh glomerulus di dalam ginjal. Jika terdapat gangguan pada fungsi filtrasi ginjal maka kadar kreatinin dalam darah akan meningkat, dan kenaikan ini dapat digunakan sebagai indikator adanya gangguan fungsi ginjal. Hasil penelitian menunjukan kreatinin dalam kisaran normal yaitu 1,18-1,48 $\mathrm{mg} / \mathrm{dl}$. Nilai normal kadar kreatinin berkisar antara 0,2-2,6 mg/dL (Meyer dan Harvey, 2004; Wahjuni dan Bijanti, 2006). Tinggi atau rendahnya kadar kreatinin dalam darah juga dapat digunakan sebagai gambaran berat ringannya gangguan fungsi ginjal (Kaneko, 2008). Perlakuan pakan komplit relatif aman bagi fungsi organ ginjal dan tidak menyebabkan gangguan.

Pemeriksaan rasio ini lebih sensitif untuk mengkaji hubungan nitrogen urea darah dan kreatinin, dibandingkan dengan pemeriksaan yang terpisah. Hasil penelitian menunjukan hasil yang berbeda nyata antar perlakuan pakan komplit. Rasio nitrogen urea darah/kreatini masih berada pada kisaran normal, yakni 11,6815,71. Kim et al. (2015) menyatakan bahwa rasio normal pada sapi yang diberi pakan kontrol adalah 8,3-17,8. Penurunan rasio dapat terjadi pada nekrosis tubulus ginjal akut, asupan rendah protein, penyakit hati, dan pascahemodialisis. Rasio akan meningkat karena penurunan perfusi ginjal, penyakit glomerulus, uropati obstruktif, atau asupan protein. Pemeriksaan rasio nitrogen urea darah dan kreatinin pada serum dapat digunakan sebagai salah satu indikator untuk mengetahui fungsi ginjal (Indriani et al., 2017).

\section{SIMPULAN}

Perlakuan pakan komplit yang mengandung sabut kelapa $15 \%$ terjadi konsumsi SK tertinggi, 
konsumsi BETN terendah dan rasio nitrogen urea darah dan kreatinin terrendah dan masih dalam kisaran normal. Perlakuan pakan komplit tidak memengaruhi konsumsi BO, BK, PK dan profil nitrogen urea darah dan kreatinin. Secara keseluruhan perlakuan pakan komplit tidak mengganggu fungsi ginjal.

\section{SARAN}

Perlu dilakukan penelitian lanjutan tentang penggunaan sabut kelapa fermentasi dalam pakan komplit yang disusun kandungan nutrien rata-rata PK 12\%, TDN 65\% untuk mengetahui persentase penggunaan sabut kelapa fermentasi yang optimal.

\section{UCAPAN TERIMAKASIH}

Terima kasih tak terhingga kepada beliau Dr. Ir. Eko Pangestu, M.P. dan Dr. Ir. Limbang Kustiawan N, S.Pt., M.P. IPU sebagai pembimbing. Terima kasih penulis ucapan kepada: 1.) kepada Beasiswa Unggulan, Direktorat Jenderal Pendidikan Tinggi, Riset dan Teknologi, Kemendikbudristek, 2. Laboratorium Ilmu Nutrisi dan Pakan, Fakultas Peternakan dan Pertanian, Universitas Diponegoro, Semarang. Laboratorium Teknologi dan Hasil Pertanian Fakultas Teknologi Pertanian, Laboratorium Biokima Fakultas Peternakan, Universitas Gadjah Mada, Yogyakarta yang telah membantu penulis sehingga penelitian ini dapat terlaksana dengan baik.

\section{DAFTAR PUSTAKA}

Adeyi O. 2010. Proximate composition of some agricultural wastes in Nigeria and their potential use in activated carbon production. J. Appl. Sci. Environ. Manage. 14(1): 5558.

Al-Fartosi KG, Talib YJ, Ali SH. 2010. Comparative study of some serum biochemical parameters of cattle and sheep of the marshes in the south of Iraq. AlQadisiya Journal of Vet Med Sci 9(2): 7884.

Arora SP. 1989. Pencernaan Mikroba pada Ruminansia. Yogyakarta. Gadjah Mada University Press.
Astuti DA, Ekastuti DR, Sugiarti. Marwah Y. 2008. Profil Darah dan Nilai Hematologi Domba Lokal yang Dipelihara di Hutan Pendidikan Gunung Walat Sukabumi. Agripet 8(2): 1-8.

Badan Pusat Statistik. 2018. Statistik Perkebunan Indonesia. Jakarta.

Cantalapiedra-Hijar G, Abo-Ismail, Carstens M, Guan GE, Hegarty LL, Kenny R, McGee DA, Plastow M, Relling G, Ortigues-Marty AI. 2018. Review: biological determinants of between-animal variation in feed efficiency of growing beef cattle. Animal 12: 321-335.

Church DC. 1993. The Ruminant Animal Digestive Physiologi and Nutrition. (Diterjemahkan oleh Srigandono B). Yogyakarta. Waveland Press,

Chuzaemi S. 2012. Fisiologi Nutrisi Ruminansia. Malang. UB Press.

Duncan, J. R. And K. W. Prasse. 1986. Effect of Lasolocid on Feedlot Performance, Energy Partitioning and Hormonal Status of Cattle. J Anim Sci 53: 417-423

Endrawati E, Baliarti E, Budhi SPS. 2010. Performans induk sapi silangan SimmentalPeranakan Ongole dan induk sapi Peranakan Ongole dengan pakan hijauan dan konsentrat. Buletin Peternakan 34(2): 86-93.

Gurung NK, Rankins DL, Shelby RA, Goel S. 1998. Effects of fum onisin b1-contaminated feeds on weanling angora goats. Journal of Animal Science 76: 2863-2870.

Hadi RF, Kustantinah, Hartadi H. 2011. Kecernaan In Sacco Hijauan Leguminosa dan Hijauan Non Leguminosa dalam Rumen Sapi Peranakan Ongole. Buletin Peternakan 35(2): 79-85.

Harjosuwono BA, Arnata IW, PuspawatiGAKD. 2011. Rancangan Percobaan Teori, Aplikasi SPSS dan Excel. Malang. Lintas Kata Publishing.

Indriani V, Siswandari W, Lestari T. 2017. Hubungan Antara Kadar Ureum, Kreatinin dan Klirens Kreatinin dengan Proteinuria pada Penderita Diabetes Mellitus. Prosiding Seminar Nasional Lokal Berkelanjutan VII. Hlm. 758-765. 
Kaneko JJ. 2008. Clinical Biochemistry of Domestic Animal. San Diego. Academic Press. Hlm. 338-394.

Kim YI, Park JM, Lee YH, Lee M, Choi DY, Kwak WS. 2015. Effect of By-product Feedbased Silage Feeding on the Performance, Blood Metabolites, and Carcass Characteristics of Hanwoo Steers (a Field Study). Asian-Australasian Journal of Animal Sciences 28(2): 180-187.

Klinkon M, Jezek J. 2012. Values of blood variables in calves. Dalam: A bird's-eye view of veterinary medicine. (Ed. CC PerezMarin) Hlm. 301-320.

Kuswati, Kusmartono, Susilawati T, Rosyidi D, Agus A. 2014. Carcass Characteristics of Brahman Crossbred Cattle in Indonesian Feedlot. IOSR Journal of Agriculture and Veterinary Science 7(3): 19-24

Maynard LA, Loosli JK, Hintz HF, Warner RG. 1979. Animal Nutrition. 7th Ed. New Delhi. Tata McGraw-Hill Pub Co Ltd.

McDonald PR, Edwards A, Greenhalg JFD, Morgan CA. 2002. Animal Nutrition. $6^{\text {th }}$ Edition. New York. Longman Scientific and Technical Co.

Meyer DJ, Harvey JW. 2004. Veterinary Laboratory Medicine Interpretation and Diagnosis. Philadelphia. Saunders. Hlm. 308.

Murray RK, Granner DK, Rodwell VW. 2006. Harper's Illustrated Biochemistry. $27^{\text {th }} \mathrm{Ed}$. USA. McGraw-Hill Co.

Murray RK, Granner DK, Mayes PA, Rodwell VW. 2003. Biokimia Harper. Edisi ke-25. Jakarta. EGC. Hlm. 195.

Nuswantara LK, Sunarso, Arifin M, Setiadi A. 2020. Komponen serat sabut kelapa yang difermentasi menggunakan mikroba pencerna serat dari rumen kerbau. Jurnal Agripet 20(1): 1-8.

Pemayun IGAGP. 2002. Mengkaji Nefrotomi Nir Jahitan pada Anjing. Jurnal Veteriner 3(2): 94-96.

Pond WG, Chruch DC, Pond KR, Schoknecht PA. 2005. Basic Animal Nutrition and Feeding. New York. John Wiley and Sons, Inc.
Promkot C, Wanapat M. 2005. Effect of level of crude protein and use of cottonseed meal in diet containing cassava chips and rice straw for lactating dairy cows. Asian-Aust J Anim Sci 18: 502-511.

Purbowati E, Sutrisno CI, Baliarti E, Budhi SPS, Lestariana W. 2007. Pengaruh pakan komplit dengan kadar protein dan energi yang berbeda pada penggemukan domba lokal jantan secara feedlot terhadap konversi pakan. Prosiding Seminar Nasional Teknologi Peternakan dan Veteriner. Pusat Penelitian dan Pengembangan Peternakan, Badan Penelitian dan Pengembangan Pertanian, Departemen Pertanian, Bogor. Hlm. 394-401.

Purbowati E, Baliarti E, Budhi SPS. 2004. Tampilan Glukosa, NH3 dan urea darah domba yang digemukan secara feedlot dengan pakan dasar dan level kosentrat yang berbeda. J Pengemb Pet Trop 1: 8185.

Sennang N, Sulina, A. Badji, Hardjoeno. 2005. Laju filtrasi glomerulus pada orang dewasa berdasarkan tes klirens kreatinin menggunakan persamaan cockroft-gault dan modification of diet in renal disease. Jurnal Medikal Nusantara 24: 80-84.

Sova AD, LeBlanc SJ, McBride BW, DeVries TJ. 2013. Associations between herd-level feeding management practices, feed sorting, and milk production in freestall dairy farms. J Dairy Sci 96: 4759-4770.

Sova AD, LeBlanc SJ, McBride BW, DeVries TJ. 2014. Accuracy and precision of total mixed rations fed on commercial dairy farms. $J$ Dairy Sci 97: 562-571.

Tillman AD, Hartadi H, Reksohadiprojo S, Prawirokusumo S, Lebdosoekojo S. 1998. Ilmu Makanan Ternak Dasar. Cetakan ke6. Yogyakarta. Gadjah Mada University Press.

Toharmat T, Nursasih E, Nazilah R, Hotimah N, Noerzihad TQ, Sigit NA, Retnani Y. 2006. Sifat fisik pakan kaya serat dan pengaruhnya terhadap konsumsi dan kecernaan nutrien ransum pada kambing. Media Peternakan 29(3): 146-154.

Utomo R. 2001. Penggunaan jerami padi sebagai pakan basal: suplementasi sumber energi 
dan protein terhadap transit partikel pakan, sintesis protein mikroba, kecernaan dan kinerja sapi potong. Disertasi. Yogyakarta. Universitas Gadjah Mada.

Uyeh DD, T.Pamulapati T, Mallipeddi R, Park T, Asemiablie S, Woo S, Kim J, Kim Y, Ha Y. 2019. Precision animal feed formulation: an evolutionary multiobjective approach. Anim Feed Sci Technol 256: 1-16.

VanSoest PJ. 1994. Nutritional Ecology of the The Ruminant. $2^{\text {nd }}$ Ed. Ithaca. Comstock Publishing Associates Cornell University Press. A Divisien of Ithaca and London.

Wahjuni RS, Bijanti R. 2006. Uji efek samping formula pakan komplit terhadap fungsi hati dan ginjal pedet sapi friesian holstein. Media Veteriner 22: 174-179.
Widhyari SD, Esfandiari A, Cahyono AD. 2015. Profil kreatinin dan nitrogen urea darah pada anak sapi Friesian Holstein yang disuplementasi Zn. Acta Veterinaria Indonesia 3(2): 45-50.

Xuan NH, Loc HT, Ngu NT. 2018. Blood biochemical profiles of Brahman Crossbred cattle supplemented with different protein and energy sources. Veterinary World 22310916. 